\title{
脳動脈瘤術後の再発，増大，新生に関する検討
}

\author{
蛯名 国彦，大熊 洋揮，岩渕隆
}

\section{Clinical Study on the Recurrent of Cerebral Aneurysm After Intracranial Direct Surgery}

Kunihiko Ebina, M.D., Hiroki Ohkuma, M.D., and Takashi Iwabuchi, M.D.,

Department of Neurosurgery, Hirosaki University School of Medicine, Hirosaki, Japan

\begin{abstract}
Summary : Study of the recurrence and enlargement of cerebral aneurysms (An) after direct intracranial surgery is important in order to elucidate of the pathogenesis and growth mechanism and to develop more reliable treatment.

By October 1985 a total of 459 cases of An, including three cases of recurrence, one case of enlargement and two of neogenesis had been experienced in our institution, and both analysis of these clinical cases and examination, of enlargement factors for 67 infundibular dilatations (ID) from 398 carotid angiograms were made.
\end{abstract}

The findings obtained are :

1. Two male patients and four female patients averaged 43 years of age at the time of the initial operation and 53 years of age at the time of recurrence.

2. Recurrence and neogenesis were observed 6 to 13 years, averaging 9 years and 10 months, after the initial operation.

3. Multiple An were observed in three cases (3/6) (including 2, 3 and 4 unities, respectively), sug. gesting extensive fragility of the intracranial artery.

4. In terms of sites of An, ICĀn showed the highest incidence [6 unities (6/12) ], followed by MCAn (3 unities), A comm An (2 unities), and ACAn (1 unity).

5. Recurrence detected was ascribable to re-bleeding (4 cases) and follow-up CT (1 case).

6. Use of malleable clip, muscle and the like seemed to be involved in the recurrence, suggesting inadaptability of the clip for the complicated morphology of An and unreliability of the muscle as reinforcement.

7. For four cases (4/6), hypertension was observed in the clinical course, and remarkable changes in blood pressure, i.e., increases in diastolic pressure, especially attracted attention.

8. All cases showed arteriosclerotic changes adjacent to the aneurysm neck to An preoperatively or at autopsy.

9. In four cases the patient returned to work; however one patient died and one remains in a vegetable state. The prognosis for cases of rebleeding is poor.

10. In terms of enlargement factors for ID, statistically significant correlations were observed among the form and size of ID in cerebral angiography, and hypertension, angle of bifurcation for internal carotid artery and posterior communicating artery, degree of development of the latter artery and the like, with very important influences of the hemodynamic stress.

These results suggested that fragility of the vascular wall, unbalance between repair mechanism

Key words :

- recurrent cerebral aneurysm

- recurrent factors

- infundibular dilatation

- hemodynamic stress

- inadaptability of the clip 
and hemodynamic stress, and so forth seemed to be responsible for the recurrence and enlargement of An, the prevention of which would require development and selection of clips comfortable to the morphology of An, reliability of reinforcement materials, control of blood pressure, and long-term follow-up observations.

\section{はじめに}

脳動脈瘤術後の再発，増大に関して検討することは，動 脈瘤発生，成長の mechanism の解明や，より確実な治療 のためにも重要なことと思われる，今回は，現在までに経 験した再発, 新生脳動脈瘤 6 症例についての臨床像の分析 や infundibular dilatation（以下 ID）の増大因子に関する検 討を行った.

\section{対象および方法}

われわれの施設においては，1973年 1 月より1985年10月 までに, 脳動脈瘤 459 症例中, 再発 3 例, 増大 1 例, 新生 2 例，計 6 症例 (1.3\%) を経験している。これら再発例に ついて, 各症例を紹介しながら, 臨床像, 経過, 再発因子 など多方面より検討を加えた。また，脳動脈瘤患者のうち 鮮明な側面像の得られた260症例，398件の頚動脈撮影(以 下 $\mathrm{CAG}$ ) から，67個の ID を検索し，その増大因子につ いて検討した。 なお，ID の診断基準は Pool and Potts ${ }^{12)}$ に従い，(1)IDの尖端に後交通動脈を認めること，(2)最大 径が $3 \mathrm{~mm}$ 以下, (3)形が円形または円錐形で囊状や不整形 を呈さない, (4)動脈瘤様の頸部を持たないことなどである. ID の大きさは小型 $(1.5 \mathrm{~mm}$ 以下), 中型 $(2.0 \mathrm{~mm})$, 大型 (2.5mm 以上) と表現した。形状は ID の頂点において, 接線を引けるものを円形, 引けないものを三角形と定義し た.

\section{症例}

\section{〈症例 1$\rangle \quad$ (730014） 45 $\rightarrow$ 53歳, 男性.}

1972年 10 月 22 日，クモ膜下出血発作. rt CAGにて, anterior communicating aneurysm (A comm An) が確認さ れ，当科に紹介となる. 1973年 1 月 23 日, 銀クリップにて neck clippingをし, 術後動脈瘤の消失を確認しているに もかかわらず, 8 年後, 1980年 7 月 31 日, 再出血をきたし, 瀕死の状態で搬送されてきた。入院時の CTでは, 前頭葉, 側頭葉，脳室系などに広沉な大出血がみられ，rt CAGで は non-filling の状態で頭蓋内压がきわめて高く, lt CAG では前回の clipping 部位に隣接して, 新たな淡い大きな 動脈瘤様㓌影がみとめられた。入院時血圧は202/110 $\mathrm{mmHg}$ と中等度の上昇を認めている. 組織学的所見では, 前回の銀クリップは既存動脈瘤柄部に clipping されてい るものの, その clip 辺縁部において弾性板や中膜筋層の
萎縮, 断裂, 消失など, 血管壁の菲薄化, 脆弱化が顕著で あり，加えてこの部に太い右 $\mathrm{A}_{1} よ り$ hemodynamic stress が加わり，動脈瘤再発に至ったようである ${ }^{1)}$ (Fig. 1).

〈症例 2〉 (801640) 51 $\rightarrow$ 57歳, 女性.

20年ほど前に，クモ膜下出血様発作の既往あり。1974年 8 月29日, 某施設において rt CAGにより右中大脳動脈分 岐部に, 球形の大きな動脈瘤が認められ，9月6日, 初回 手術がなされた. broad neckのために, かるく結紮後, 凝固処理を加えて柄部を狭細化したのち，3 本の銀クリッ プで clipping, さらには muscleにて wrapping 補強したに もかかわらず, 6 年後, 1980年 8 月28日, follow-up CT にて，以前と同様の部位に，同じような形をした動脈瘤の 再発を認めており, muscleの wrapping 材質としての適性 に疑問をいだかせた 1 例であった。なお，血圧は210/110 $\mathrm{mmHg}$ と中等度の上昇を認めている.

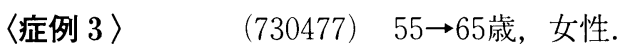

1973年11月 17 日, クモ膜下出血で発症, 精査にて left internal carotid-posterior communicating aneurysm (ICPC An), left middle cerebral aneurysm (MC An)を確認 し，11月29日，当時の V 型 malleable clip にてそれぞれを clipping したが, 術後の CAGにていずれの clip も離開し ており，MC An は消失していたが， IC-PC Anは残存し ており，12月 4 日残存動脈瘤を Heifetz clip にて再び clippingした，術後の CAGにて多少 neck が残存していたよ うであるが，10年後，1983年 8 月，再出血をきたし，某医 に入院, 家人の希望にて, ventriculo-peritoneal shunt の み施行, 現在 vegetable stateである.

\section{〈症例 4〉 (833292） 53 $\rightarrow$ 64歳, 女性.}

1972年11月 27 日, クモ膜下出血で発症, 精査にて lt ID, left anterior cerebral aneurysm (AC An), rt MC An, A comm An などを認めた多発性脳動脈瘤患者であるが, 1973年 1 月 5 日, 某施設における初回手術では, 右中大脳 動脈瘤のみ neck clipping し，ほかはいずれも小さいため (ID : $3 \times 2.5 \times 3 \mathrm{~mm}$, ACAn $: 3 \times 2.5 \times 2.5 \mathrm{~mm}$ ), followup していたところ，11年後，1983年 8 月 21 日，再出血発 作，左動眼神経麻痺をきたして当科へ紹介入院となった. lt $\mathrm{CAG}$ では AC An が $5 \times 3.5 \times 4 \mathrm{~mm}$ ，また ID が $6 \times 6.5$ $\times 5 \mathrm{~mm}$ と残存動脈瘤のいずれもが大きく成長しており, 


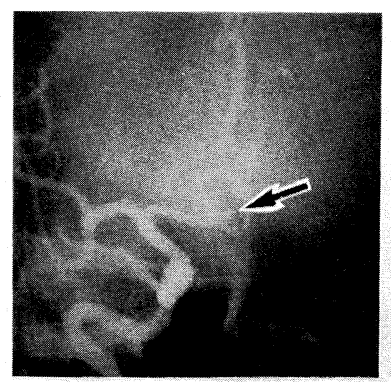

rt CAG 1972.10 .24

A COMM An

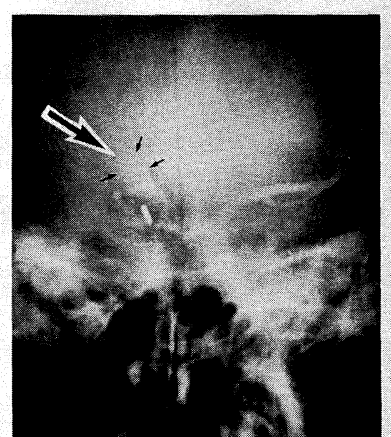

It CAG 1980. 8. 1

A COMM An RECURRENT !

rt CAG NON-FILLING

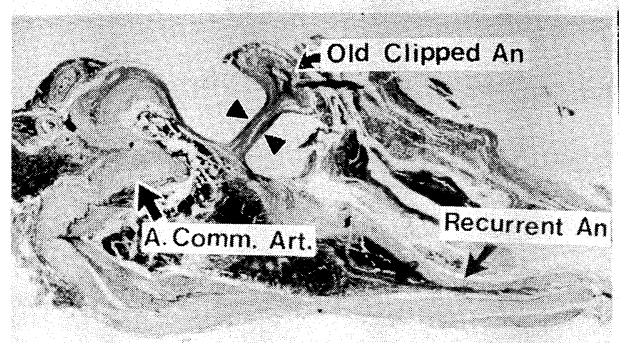

RECURRENT AN WALL

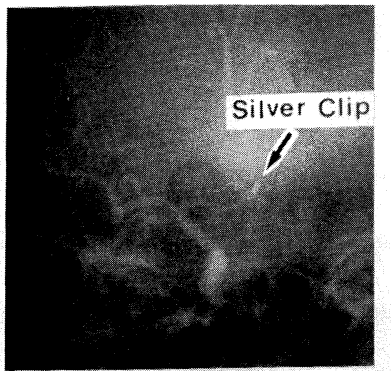

rt CAG 1973.1.26

A COMM An (-)

8 years after

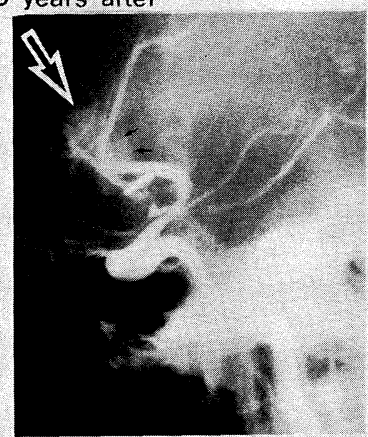

特に ID が大きな IC-PC An に成長しているのが注目され， まさしく“動脈瘤は生きている”ことを痛感させられた症 例であり (Fig. 2)，これら小動脈瘤の follow-up ならびに より確実な治療法の重要性の認識を新たにし, 最近では極 力 Bemsheet ${ }^{\circledR}$ (Bemlyse: 延岡, 旭化成製造, 大阪, 河本 包带販売)を用いて wrapping し，その成長を防止しよう と試みている。

\section{〈症例 5〉（850623） 34 $\rightarrow$ 46歳，男性.}

1973年 3 月 28 日，クモ膜下出血，複視，左眼瞼下垂で発
症. 6 月 5 日, IC-PC An の clipping の際, 左内頸動脈を 損傷し dura を用いて wrapping，止血補修操作に伴い閉塞 させている．12年後，1985年10月19日，再出血をきたし入 院した。入院時の脳血管撮影では, right internal carotid bifurcation (IC bifurc.) 部と left internal carotid-anterior choroidal artery (IC-ant. cho. art.) 部それぞれに新たな動 脈瘤の形成を認めた (Fig. 3) 。出血は CT, 術中所見より rt IC bifurc Anによるものと思われた。本例においては, 入院時血圧は $230 / 160 \mathrm{mmHg}$ ときわめて高く，また，経過 中にも著明な変動を認めた。左内頸動脈は今回の CAG で 


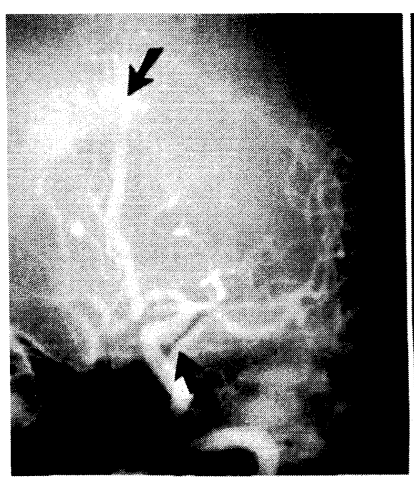

(1973.12.14)

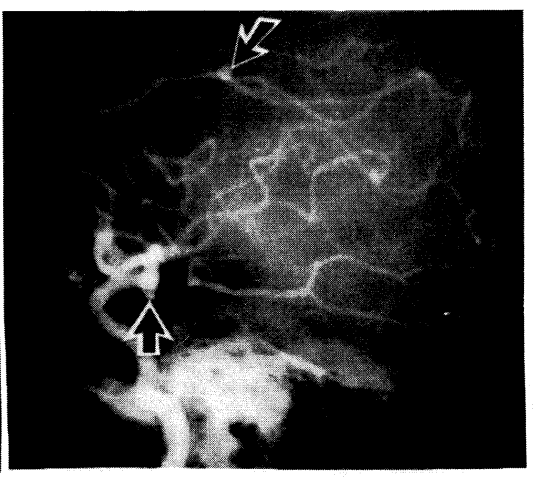

Lt. AC An $(3 \times 2.5 \times 2.5 \mathrm{~mm})$

Lt. Infundibular Dilatation $(3 \times 2.5 \times 3 \mathrm{~mm})$ (After 10 Years)
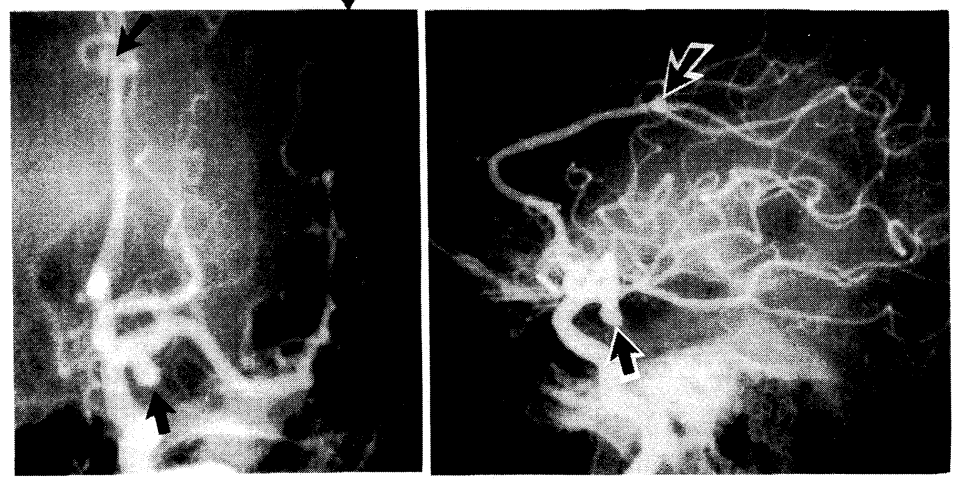

(1983.8.31)

Lt. AC An $(5 \times 3.5 \times 4 \mathrm{~mm})$

Lt. $1 \mathrm{C}-\mathrm{PC}$ An $(6 \times 6.5 \times 5.5 \mathrm{~mm})$ A

Fig. 2 Case 4. Left carotid angiogram, 10 years after the initial surgery, showing an enlarged internal carotid-posterior communicating junctional aneurysm (IC-PCAn) and anterior cerebral arterial aneurysm (AC An).

は再開通していたが，内頸動脈閉塞に伴う対側内頸動脈へ の hemodynamic stress の増強や, flow patternの変化な どに加え, 術中 neck 近傍に高度の限局性動脈硬化も認め ており，これらの後天的因子が重要のようである(10).

\section{〈症例 6〉 (860215） 20 $\rightarrow$ 33歳，女性.}

1971年 6 月頃より徐々に右眼充血, 眼球突出, 複視, 頭 痛，嘔気，嘔吐などがみられるようになり，rt CAGにて idiopathic CCF と dural A-V malformationをみとめ, 1972年 3 月 15 日, 右頸部頸動脈を結紮, その後も症状の軽 快が得られないため，1973年 2 月 9 日，右頭蓋内内頸動脈 の clipping, その後, 右頸部頸動脈の再開通を認めたため, 3 月 1 日頸部総頸, 内頸，外頸動脈それぞれを結紮，切断 している.その後, 症状の軽快をみていたが, 13年後, 1986年 1 月28日，突然，頭痛，嘔気，嘔吐などの発作をみ とめた。 入院時の精査ではクモ膜下出血は認められなかっ たが, lt CAGにて IC-ophthalmic Anの新生を認めた.
本例においては血圧は $102 / 78 \mathrm{mmHg}$ と高くはないものの, ほかに両側 CCF, dural A-V malf. などの合併を認めるこ とから(Fig. 4)，血管壁の広範な脆弱性を背景に右頸動脈 結㮃に伴い, 対側内頸動脈領域への hemodynamic stress 増強などの負荷が加わり動脈瘤新生に至ったものと思われ る.

\section{ID の成長因子に関する検討}

398件の CAG から67個の ID を渉猟し，その出現頻度， 形態に関し，詳細な検討を加え，以下の知見を得た。

1. ID の出現頻度は，従来の一般症例対象の報告で は $\left.{ }^{13)} 15\right) 10 \sim 15 \%$ (対症例数), 5〜10\% (対CAG数)である のに比し，われわれの脳動脈瘤症例においてはそれぞれ $24.6 \%, 16.8 \%$ と約 2 倍の高率を示し, ID と脳動脈瘤の 間に相関がうかがえる。

2.小型の ID では三角形を呈することが多く，大きく なるに従い円形が増加する傾向にある $(p<0.01)$. 


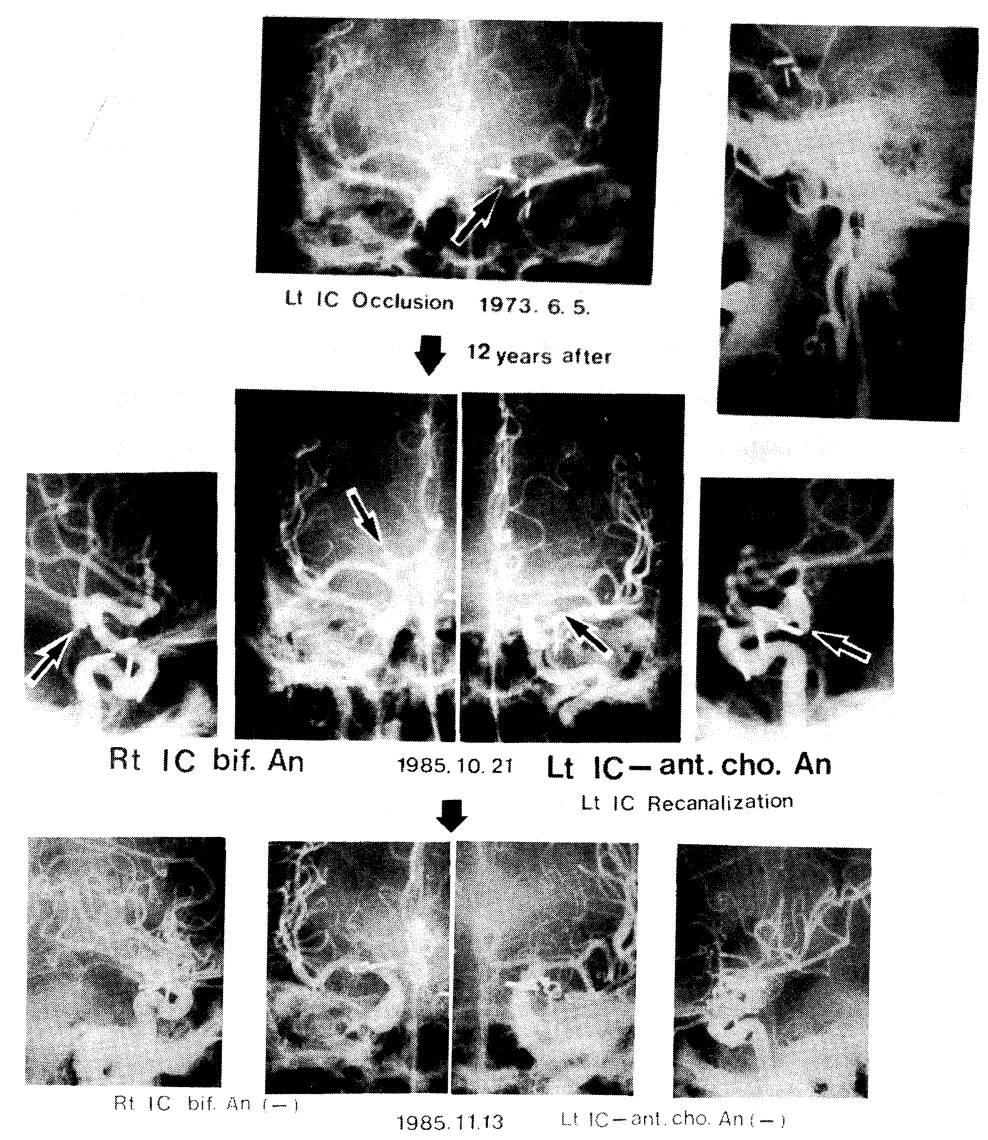

Fig. 3 Case 5. Carotid angiograms, 12 years after the initial operation, revealing a newly development of a right internal carotid bifurcation aneurysm and a left internal carotid-anterior choroidal junctional aneurysm (IC-ant. cho. An).

3. 若年者では大型の ID を占める比率が $83.3 \%$ で他の 年代に比し有意に高率であった $(p<0.05)$.

4. IC-PC An 群において, ID の出現頻度は $29.7 \%$ ，ま た，中型以上，円型のIDの比率が $72.7 \%$ とそれぞれ有意 に高率であった $(P<0.05)$.

5. 高血圧の既往を有する症例に掞いては, 大型の ID の比率が $41.2 \%$ と有意に高率であった $(P<0.05)$.

6. 後交通動脈の発達程度に関しては, 後交通動脈内径 が，1.5mm 以上のより太いものほど，また，後大脳動脈 末梢まで造影されるものほど，大型，円形のID がそれぞ れ $58.6 \% ， 61.1 \%$ と有意に高率を示した $(p<0.01)$ (Fig. 5).

7. CAG 正面像において, 内頸動脈と後交通動脈の分 岐角度に関しては，90末満群では中型以下，三角形の ID が $83.3 \% ， 90^{\circ}$ 以上群では中型以上，円形の ID が $46.7 \%$ とそれぞれ高率を示しており $(p<0.05)$, 一方, $60^{\circ}$ 未満 の15例においては，IDを合併したものは 1 例もなく興味 深い.これらの事実もまた, hemodynamic stress の影響 がきわめて大きいことを示していると思われる。

\section{考察}

脳動脈瘤の成因や増大の機序に関しては，先人により， 数多〈の知見が得られ4)7)8111), 病理組織学的, 流体力学 的，あるいは臨床的な面からの検討が種々なされてきた。 しかし, 脳動脈瘤術後の再発, 増大に関して検討すること もまた，意義あることのように思われる．われわれの症例 の臨床像を検討してみると, 初回手術後6 13年間 (平均 9 年10か月)に動脈瘤の再発や新生がみられており，血管壁 の脆弱性や hemodynamic stress が加わると, この期間内 でも，動脈瘤は形成しうることになる．男性 2 例，女性 4 例で女性が $2 / 3$ を占め, 初回手術時平均年齢は 43 歳, 再発 時年齢53歳であり，他の動脈瘤群に比し若年傾向にある. 動脈瘤部位は内頸動脈瘤 6 個 (6/12) で最多であり, 他 MC An 3, A comm An 2, AC An 1などがみられた, 再発発 見の動機は再出血 4 例 follow-up CT 1 例, 頭痛発作 1 例 であり, 多くは再出血発作により発見されているが, 症例 2のように再出血前にfollow-up CT で発見しえた例もあ り，術後の侵襲の少ないfollow-up studyの 1 つとして有 

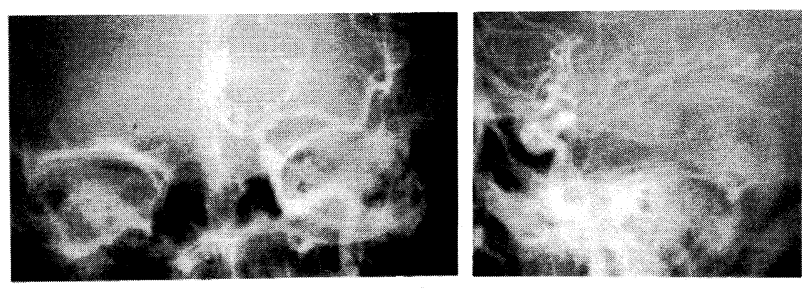

1973. 1.24

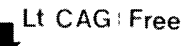

1973. 2.9 Clipping of Rt Intracranial ICA

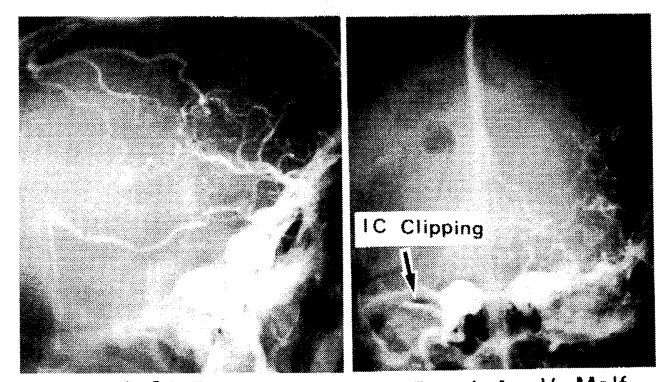

1973. 2. 24 Rt CAG $\rightarrow$ CCF. Dural $A-V$ Malf.

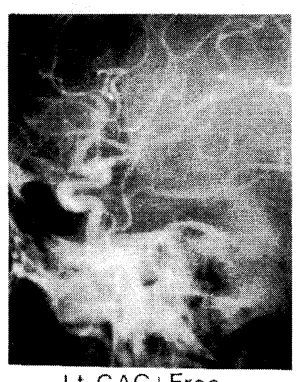

Lt CAG: Free

1973. 3.1 Ligation of Rt CCA,ICA and ECA

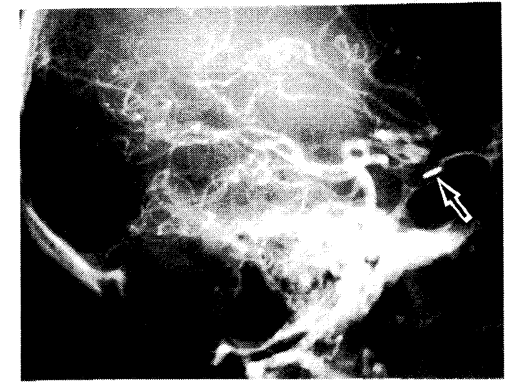

1986. 1. 29 Rt ICA (-)

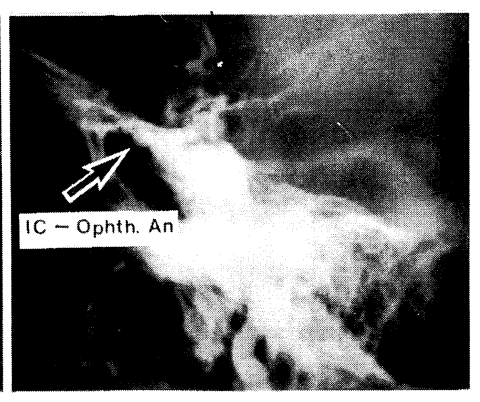

Lt IC-Ophth. An! Lt CCF (Rt $A-V A G$ )

Fig. 4 Case 6. Left carotid angiogram, 13 years after the initial procedure, showing a new internal carotid-ophthalmic junctional aneurysm (ICophth. An).

益であり，さらに digital subtraction angiography を併用 するとより効果的と思われる(Table 1). 再発因子としては, Table 2にみられるごとく, 新生例はいずれも内頸動脈瘤閉 塞後にみられており, 対側内頸動脈領域への hemodynamic stress は予期以上に大きくなるようである。これは

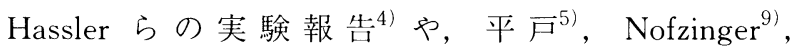
Somach ${ }^{14)} ら$ の頸動脈結紮後に新たな動脈瘤発生をみた とする報告などからも肯首しうる事実である. 高血圧の因 子も重要で, 経過中に高血圧を認めたものは 4 例 (4/6), 特に著明に血圧の変動, 拡張期血圧の上昇が注目される. 動脈瘤柄部近傍の親動脈などには, 内膜水腫, 粥状硬化, 内膜肥厚, 弾性線維菲薄化, 断裂, 中膜筋層の萎縮などの いわゆる動脈硬化性病変が術中, または剖検において全例 に観察されている。また多発性動脈瘤例, 硬膜動静脈奇形, idiopathic CCF の合併など，頭蓋内血管の広範な脆弱性 を示唆する症例もみられる. 今回の再発例はすべて当時の malleable clip が用いられており, clip が複雑な動脈瘤の 形態に適応しきれなかったこと, clip 辺縁部における中膜, 弾性板の断裂，消失などの血管壁の脆弱化などが示唆され て抢り, 適切な clip の開発, 選択もまた重要と思われる. 加えていずれの症例においても hemodynamic actionの直 撃をうける方向に動脈瘤が発育, 増大して抢り, ことに内 頸動脈瘤の発生部位はSyphon 部のカーブの度合にも関連 があるようである。転帰は社会復帰 4 , 植物状態 1 , 死亡 1 例で再出血例は予後不良であり, 今後より一層, 術後の 慎重な follow-up が必要のように思われる ${ }^{1) 6)}$ 。また，ID の増大因子として, 脳血管撮影上の ID の形態や大きさと 高血圧の有無, 内頸動脈と後交通動脈の分岐角度, 後交通 


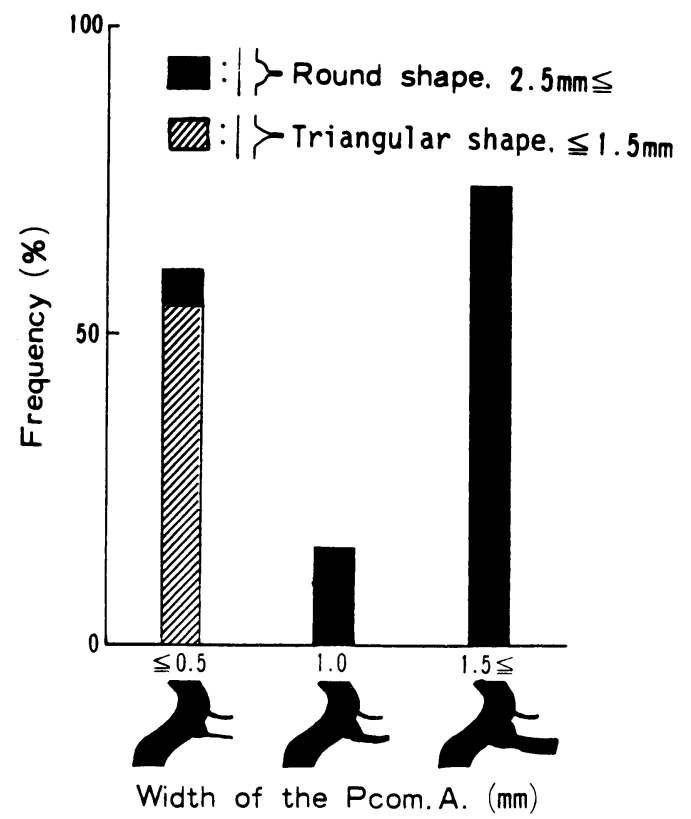

Fig. 5 Frequency distribution of the shape and size of infundibular dilatation (ID) by the width of the posterior communicating artery (P com A.).
動脈の発達程度などに有意の統計学的相関を認めており, このことからも hemodynamic stress の影響はきわめて大 と思われる3)

\section{結 語}

以上のことから，脳動脈瘤の再発，増大，新生は，血管 壁の脆弱化, 修復機転, hemodynamic stress などの脳動 脈壁に関する生体機能の unbalance のうえに発生するもの であり，その防止には，動脈瘤の形態に即した $\operatorname{clip} の$ 開 発と適切な選択, 補強材質の検討, 血圧の control, 長期間 の慎重な follow-up などが重要と思われた.

\section{文献}

1) Ebina K, Suzuki M, Andoh A, et al : Recurrence of cerebral aneurysm after initial neck clipping. Neurosurgery 11 : 764-768, 1982

2) Ebina $\mathrm{K}$, Iwabuchi $\mathrm{T}$, Suzuki S : A clinico-experimental study on various wrapping materials of cerebral aneurysms. Acta Neurochir (Wien) 72:61-71, 1984

Table 1 Summary of the recurrent cerebral aneurysms - Clinical features -

\begin{tabular}{|c|c|c|c|c|c|c|c|}
\hline Case & Sex & $\begin{array}{l}\text { Age } \\
\text { (yo) }\end{array}$ & $\begin{array}{l}\text { Ope-recurr } \\
\text { interval(yr) }\end{array}$ & $\begin{array}{l}\text { Initial } \\
\text { site }\end{array}$ & $\begin{array}{l}\text { Recurrent } \\
\text { site }\end{array}$ & No. of $\mathrm{An}$ & $\begin{array}{l}\text { Detective } \\
\text { trigger }\end{array}$ \\
\hline 1 & M & $\begin{array}{c}45 \\
\downarrow \\
53\end{array}$ & 8 & A. comm. An & $\rightarrow$ A. comm. An & 1 & $\mathrm{SAH}$ \\
\hline 2 & $\mathrm{~F}$ & $\begin{array}{l}51 \\
\downarrow \\
57\end{array}$ & 6 & rt MC An & $\rightarrow \mathrm{rt} \mathrm{MC} \mathrm{An}$ & 1 & $\begin{array}{l}\text { follow-up } \\
\text { CT }\end{array}$ \\
\hline 3 & $\mathrm{~F}$ & $\begin{array}{l}55 \\
\downarrow \\
65\end{array}$ & 10 & $\begin{array}{l}\text { It } \mathrm{IC}-\mathrm{PC} \mathrm{An} \\
\text { rt } \mathrm{MC} \mathrm{An}\end{array}$ & $\rightarrow \mathrm{rt} \mathrm{MC} \mathrm{An}$ & 2 & $\mathrm{SAH}$ \\
\hline 4 & $\mathrm{~F}$ & $\begin{array}{l}53 \\
\downarrow \\
64\end{array}$ & 11 & $\begin{array}{l}\text { It infund. dilat. } \\
\text { lt AC An } \\
\text { A. comm. An } \\
\text { rt MC An }\end{array}$ & $\begin{array}{l}\text { It IC-PC An } \\
\rightarrow \text { It AC An } \\
\text { A. comm. An }\end{array}$ & 4 & SAH \\
\hline 5 & M & $\begin{array}{c}34 \\
\vdots \\
46\end{array}$ & 12 & lt IC-PC An & $\begin{array}{l}\text { lt IC-A. cho. An } \\
\text { rt IC bifurc. An }\end{array}$ & 3 & $\mathrm{SAH}$ \\
\hline 6 & $\mathrm{~F}$ & $\begin{array}{c}20 \\
1 \\
33\end{array}$ & 13 & $\begin{array}{l}\text { rt } \mathrm{CCF} \\
\text { dural A-V malf. }\end{array}$ & $\begin{aligned} & \text { dural A-V malf. } \\
& \text { lt CCF } \\
& \rightarrow \text { lt IC-ophth. An }\end{aligned}$ & 1 & headache \\
\hline
\end{tabular}

730014, 801640, 730477, 833292, 850623, 860215: A. comm. An: anterior communicating artery aneurysm,

MC An: middle cerebral artery aneurysm, IC-PC An: internal carotid-posterior communicating artery aneurysm,

AC An: anterior cerebral artery aneurysm, IC-A. cho. An: internal carotid-anterior choroidal artery aneurysm,

IC bifurc. An: internal carotid-bifurcation aneurysm, Infund. dilatat. : infundibular dilatation, SAH: subarachnoid haemorrhage, CCF: carotid-cavernous fistula, A-V malf.: arterior-venous malformation,

IC-ophth. An: internal carotid-ophthalmic artery aneurysm, CT: computed tomography. 
Table 2 Summary of the recurrent cerebral aneurysms - Recurrent factors -

\begin{tabular}{|c|c|c|c|c|c|c|c|}
\hline \multirow{2}{*}{ Case } & \multicolumn{6}{|c|}{ Recurrent factors } & \multirow{2}{*}{ Outcome } \\
\hline & IC occlusion & Hypertension & Sclerosis & $\begin{array}{l}\text { Vascular } \\
\text { Fragility }\end{array}$ & Malleable clip & $\begin{array}{c}\text { Hemodynamic } \\
\text { action }\end{array}$ & \\
\hline 1 & & H & 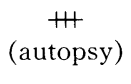 & - & + & & dead \\
\hline 2 & & H & $\begin{array}{l}\text { H+ } \\
\text { (ope) }\end{array}$ & - & + & & $\begin{array}{l}\text { full } \\
\text { recovery }\end{array}$ \\
\hline 3 & & $H$ & $\begin{array}{l}\text { H+ } \\
\text { (ope) }\end{array}$ & + & + & & vegetable \\
\hline 4 & & \pm & $\begin{array}{l}\text { +\# } \\
\text { (ope) }\end{array}$ & H+ & + & & $\begin{array}{c}\text { full } \\
\text { recovery }\end{array}$ \\
\hline 5 & $\begin{array}{l}\text { IC occlusion } \\
\text { (transient) }\end{array}$ & H & $\begin{array}{l}+ \\
\text { (ope) }\end{array}$ & - & + & & $\begin{array}{l}\text { full } \\
\text { recovery }\end{array}$ \\
\hline 6. & IC trapping & - & $\begin{array}{c}- \\
\text { (ope) }\end{array}$ & m & - & & $\begin{array}{l}\text { full } \\
\text { recovery }\end{array}$ \\
\hline
\end{tabular}

3) Ebina $\mathrm{K}$, Ohkuma $\mathrm{H}$, Iwabuchi $\mathrm{T}$ : An angiographic study of incidence and morphology of infundibular dilatation of the posterior communicating artery. Neuroradiology. 28 : 23-29, 1986

4) Hassler $\mathrm{O}$ : Experimental carotid ligation followed by aneurysmal formation and other morphological changes in the circles of Willis. J Neurosurg $20: 1-7,1963$

5）平戸政史, 深町 彰, 豊田収, ほか：脳動静脈奇形, 孔 脳症を有し, 総頸動脈結皆術後, 脳動脈瘤の新生をみた 1 例. 神経外科 $23: 163-166,1983$

6）池田清延，早瀬秀男，林 実，ほ力：前脳動脈瘤病変と脳 動脈瘤の新生。脳神経外科 12:1151-1158, 1984

7）森竹浩三：脳動脈瘤の成因ならびに増大，破裂機序に関す るバイオメカニクス的研究. 第 1 部 脳動脈の組織構築と 力学的特性に関する研究. 日本外科宝函 44:87-107, 1975

8）森竹浩三：脳動脈瘤の成因ならびに増大，破裂機序に関す るバイオメカニクス的研究. 第 2 部 脳動脈分岐部㧍よび 脳動脈瘤内の血流動態に関する血行力学的研究. 日本外科 宝函 44：108-123, 1975

9) Nofzinger JD, Britt LG, Murphey F, et al : Unusual treat- ment of an intracranial aneurysm contralateral to a previous common carotid ligation. J Neurosurg $22: 182-184$, 1965

10）貫井英明, 長屋孝雄, 宮城 修, ほか: 脳動脈瘤の成因扔 よび增大, 破裂に関する臨床的検討. 神経外科 22 ： 437-445, 1982

11）大原宏二，鈴木二郎：脳動脈瘤の発生，破裂，修復及び発 育に関する臨床病理学的研究. 脳と神経 29：1103-1114, 1977

12) Pool JL, Potts DG : Aneurysms and Arteriovenous Anomalies of the Brain : Diagnosis and treatment, Harper and Row, New York, 1965, pp 132-133

13) Saltzman GF : Infundibular widening of the posterior communicating artery studied by carotid angiography. Acta Radiol 51 : 415-421, 1959

14) Somach FM, Shenkin HA : Angiographic end-results of carotid ligation in the treatment of carotid aneurysm. J Neurosurg 24:966-974, 1966

15）渡辺光夫，尹清市，倉本進賢：後交通動脈における junctional dilatationについて. 脳神経外科 $3: 917-924,1975$ 